Original scientific article

UDC: 94(100)"1916/1918"

355.415.6(469)"1916/1918"

DOI: $10.25106 / \mathrm{ahm} .2017 .1711$

\author{
António Paulo Duarte \\ National Defense Institute \\ Contemporary History Institute of the Faculty \\ of Social Sciences and Humanities \\ Nova University \\ Avenida de Berna, 26-C / 1069-061 Lisbon, Portugal \\ E-mail: apdaviduarte@gmail.com
}

\title{
THE PORTUGUESE HEALTH SERVICE IN WORLD WAR ONE: HISTORY AND MEMORY*
}

\begin{abstract}
This article aims to shed light on the Portuguese army's medical organization and action during World War One, and will be divided into three chapters. The first one presents a global context about Portuguese belligerency and how the Health Service worked during the war. The second chapter, describes the Service's organization as well as its inherent difficulties to provide support to the troops in the operational theatre. In the third chapter, one can find a state of the art about the theme in study, specifically comprised of a panoply of texts and books written about health issues related to Portuguese belligerency in World War One.
\end{abstract}

Keywords: Portugal, First World War, health services, military medicine, physicians

\section{Introduction}

Portugal was a small belligerent country in World War One, a small nation of 6.000.000 inhabitants, albeit with a large empire. Indeed, Continental Portugal, together with the Madeira and Azores archipelagos reached a mere $91.000 \mathrm{~km}^{2} . \mathrm{Nev}$ ertheless, taking the empire into account, the country had, at one point, sovereignty over a $2.500 .000 \mathrm{~km}^{2}$ territory. However, as large as its possessions were, it was lacking in population size. In fact, Angola and Mozambique, the two most sizable

\footnotetext{
* The author would like to show his gratitude to Frederico Benvinda, Mónica Oliveira and Sofia Macedo,
} interns at the Portuguese Institute of National Defense, for their work on revising this article. 
colonial areas the country had control over, only reached 3.000.000 inhabitants in total. Other territories - such as Guinea Bissau, Cape Verde, East Timor and the small colonial presence in India - had, in each case, only a few hundred thousand inhabitants. As Celestino de Almeida [1], Minister of the Navy in the Portuguese Parliament put it, Portugal was: "A small country with a great empire". Yet, as the minister acutely noted, it was, indeed, missing the population to occupy such a vast territorial expanse.

As such, Portugal's experience in the Great War can be considered unusual and peculiar when compared to that of other belligerent countries. However, Portugal did share some similarities in its experience with a particular group of nations: small European belligerent countries, which, during World War One, it can be argued, fought for one goal: to defend their homeland. In contrast, bigger countries fought for international influence and for the defeat of their enemy, which they argued could be achieved through the gaining of territorial control over various parts of the enemy's land.

Hence, larger powers, many times thanks to their own imperial possessions, were able to pool resources from all over the world, or at least, from wherever the territories of their empires stretched to. Portugal though, within the framework of a smaller yet colonial country, fought not only to defend its homeland, but mainly to assure its international position and status as a great power, category it was seen as being included in by many in Portugal, thanks to the country's empire.

To sum up, Portugal's military participation in the Great War is what one could call expeditionary, since the country mobilized about 100.000 troops during the War and almost all of them fought in distant war theatres, mainly in Flanders, France and Africa. Consequently, in order to maintain the operability of these expeditionary forces, the army had to equip them. As we shall discuss, one of the areas where this was more apparent, was the army's Health Service. During peace time, the Service was integrated into the army's General Staff and had men stationed in every divisional command. With the declaration of belligerency and the mobilization of the expeditionary forces, there was, consequently, a force mobilized specifically to serve in the Health Service.

Nevertheless, Portugal was not only a small, but also a poor country, with a high percentage of analphabetic population. Indeed, higher education only grazed a very small minority of the population, which led to a significant lack of medics and professionals trained in medical disciplines. In that sense, mobilization of personnel for the Health Service was quite difficult and permanently lacking.

Two historians have studied the Portuguese military's Health Service during World War One. Luís Alves Fraga [2-4] had study the service in the context of his studies on the Portuguese Expeditionary Corps sent to Flanders in 1917. Margarida Portela [5-7] studies are more focused in the war experiences of Portuguese medic personnel in the framework of the history of social and individual representations, or the "History of the Memory". 
Henceforth, this article aims to shed light on the Portuguese army's medical organization and action during World War One, and will be divided into three chapters. The first one presents a global context about Portuguese belligerency and how the Health Service worked during the war. The second chapter, describes the Service's organization as well as its inherent difficulties to provide support to the troops in the operational theatre. In the third chapter, one can find a state of the art about the theme in study, specifically comprised of a panoply of texts and books written about health issues related to Portuguese belligerency in World War One. Besides some technical works, this paper also analyses interesting memories and diaries written and published by doctors who were mobilized during the war.

In general, these chapters intend to give the reader a global vision of the Portuguese military's Health Service during World War One. If such vision is accomplished, this article will have achieved its purpose.

\section{Portugal in World War One}

The II German Reich declared war on Portugal on the $9^{\text {th }}$ of March 1916, making Portugal's entry into the war official. The German declaration of war on Portugal shed a light on the complexities of Portuguese intervention in World War One. Indeed, the Reich considered the armed, compulsive and unilateral requisition of control over German merchant ships harboured in Portuguese ports by the Portuguese Republic a Casus Belli. Yet, it should be noted that the Portuguese requisition of control over Triple Alliance vessels moored in its ports responded to an appeal by its oldest ally, Great Britain. In fact, they saw such Triple Alliance ships as compensation for British vessels lost through the German submarine campaign. Nevertheless, as a neutral country, and according to international law regarding maritime and war conventions, Portugal had the obligation to ensure the safety and security of merchant ships present in its ports, even those belonging to belligerent countries. Such was the particular situation of 70 ships harboured in the Portuguese waterfront found themselves in, since they were German and Austro-Hungarian [8 pp 137-190].

In spite of such, Portugal had already come into conflict with German troops before the II German Reich declared war on the country. Veritably, when World War One started, the Portuguese government had almost immediately sent two military expeditions to Africa: one to Angola and another to Mozambique, both battalion sized.

In fact, Lisbon was afraid of what might happen to its colonial possessions in the midst of a rivalry between great powers (in two past occasions - 1898 and 1912-1913 - Germany and Great-Britain had negotiated the possible partition of Portuguese colonial possessions). From Portugal's perspective, a war between global powers represented a menace to the preservation of its territorial possessions in Africa, if it decided to stay out of the conflict. 
As such, four incidents in 1914 were interpreted as a confirmation of Germany's ambitions. The first happened in Maziúa, Mozambique, on the $25^{\text {th }}$ of August that year, when a Portuguese frontier post was attacked by a German force. The second occurred on the $19^{\text {th }}$ of October, at the border between Angola and Germany's West African provinces, when a small German force was intercepted and killed by Portuguese forces (mainly due to miscommunication). As a consequence, on the $31^{\text {st }}$ of October, a German force attacked the Cuangar frontier post, killing several soldiers of the Portuguese garrison. The fourth was the battle of Naulila, in Angola, on the $18^{\text {th }}$ of December, which ended with the defeat of the Portuguese forces present in the conflict [9 pp 34-38].

In spite of these initial clashes, Portugal kept a neutral posture. Such, we argue, results from Great Britain's position in refuse to support a possible Portuguese declaration of war on II German Reich. Nevertheless, Portugal never officially declared its neutrality; from 1914 to 1916, Portugal was in an ambiguous international position, as it declared that it was firmly on the side of its oldest ally, Great Britain, but without being a belligerent power.

That ambiguity could only have been solved by the German Reich itself. Portugal's entrance into World War One was hence finally consubstantiated with Germany's declaration of war on the $9^{\text {th }}$ March 1916, following the seizure of German merchant ships harboured in several Portuguese ports, as stated, which was induced by France with simple diplomatic manoeuvre: asking Portugal to make the seizure of the Triple Alliance ships effective. Great Britain, in its own right, had to follow suit, in due respect to its alliance with Portugal. Paris was also the main inductor of the creation of the Portuguese military's expeditionary force, since it proposed to London that the presence of a few thousand Portuguese soldiers in French soil was

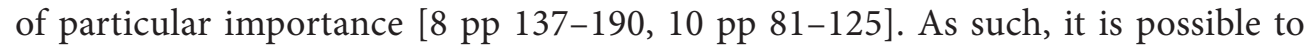
conclude that Portugal fought in three war theatres at one point or another: Europe, Africa and the Atlantic Ocean.

In Africa, as we have already been able to establish, there was fighting in Angola in 1914, and again in 1915, against an uprising of native tribes, which resulted from a Portuguese retreat after being defeated by the Germans in the previous year.

The occupation of the South West African German Colony in 1915 by the South Africa, though, put an end to the German threat to the South Angolan borders. The definitive end of the threat to Portuguese sovereignty in Angola came with the successful conclusion of the campaign against the uprising natives in the end of 1915. However, the situation in Mozambique during World War One was more complex. Fighting in East Africa extended from 1914 to 1918 and the East African Portuguese colony suffered an invasion by German forces from November 1917 to September 1918. As a response, Portugal sent several metropolitan military expeditions to Angola and Mozambique. In total, 30.000 metropolitan troops fought in these war theatres. Besides the metropolitan forces, a number of indigenous troops -16.000 men at least — were also mobilized between 1914 and 1918. 
Having stated such, however important was the African war theatre, Europe was seen in Lisbon as the most important area of conflict for the country. At least 58.000 Portuguese troops, in the Portuguese Expeditionary Corps [Corpo Expedicionário Português (CEP)], were sent to the French front lines. For the Portuguese government, these missions meant international visibility and bargaining power. Regardless, a defeat in the $9^{\text {th }}$ April 1918, at the so-called "Battle of the Lys" (Batalha do Lys), marked this military expedition. Such was also the first day of Operation Georgette, the second Ludendorff assault on British positions in 1918.

The third war theatre Portuguese forces were present in, was the Atlantic. It was a naval theatre and the only one where the fighting occurred closest to, and in some cases inside the Portuguese metropolitan homeland (inside national waters, that is) [data in Fraga, 3 pp 520-521].

As we have stated, the Portuguese army's experience during the Great War was expeditionary. Portuguese forces, even when they fought in territories under Portuguese sovereignty, were thousands of miles away from their homeland and their primary logistical base. In total, Portugal sent away nearly 100.000 troops from 1914 to 1918 .

It is necessary to underline though, that, for Portugal, a fourth war theatre was also a reality during the war, although an odd one. In fact, Continental Portugal itself was an area where various clashes took place. Those skirmishes, however, weren't against the II Reich. Indeed, they happened between Portuguese political parties and ideological factions. A quasi civil war existed in Portugal during these years, dividing factions with opposing views of the country. Radical republicans, conservative republicans, monarchists, Catholics, anarchists and others, other than discussing their vision for the future of Portugal, fought to impose their perspective of the nation on others.

The social, economic and political crisis that started at the end of nineteen century was also exacerbated by the proclamation of the Portuguese Republic in 1910, after an armed revolution. Intervention in the World War was hence seen by the radical republican government as a solution for the consolidation of the Portuguese Republic internally and externally. Interventionism exacerbated national division and produced violent political clashes between interventionists and non-interventionists [11]. The realities we described above were, as such, the context where the Portuguese Health Service in World War One operated.

\section{The Portuguese Military's Health Service System}

According to the 1911 Army Organization Law (Government Diary, no 122, $26^{\text {th }}$ of May, 1911), a Health Service was to be integrated into the army. According to the law, the Health Service Department was part of the General Staff, being led by a Colonel ( $\operatorname{art}^{\circ} 222$, p. 2150), and was hence endowed with several missions, including the pursuit of statistical studies. The Department also had the duty of studying the 
drugs and the quantities of said drugs that should be purchased by the Army, both in peace and in war times. It was also its mission to elaborate proposals regarding where army hospitals and other health facilities should be built. The study of troop's hygiene and the quality of the rations was also part of its obligations. As well as such missions, The Department, according to the law, must also pursue research and elaborate instructions regarding the preparation and training of the military's Health Service for war. In accordance to this this last duty, the Health Service Department undertook the elaboration of a campaign field manual (Regulamento para o Serviço de Campanha) ( $\operatorname{art}^{\circ} 280$, p. 2153).

Officially, there were three first class hospitals in Portugal (two in Lisbon and one in Oporto), and two second class hospitals (Coimbra and Chaves), followed by regimental hospitals and military infirmaries ( $\operatorname{rrt}^{\circ} 140$, p. 2145). Each active division also had a health company, and each reserve division, a health section ( $\operatorname{art}^{\circ} 3, \mathrm{p}$. 2139). As such, it is possible to conclude that before World War One, the Portuguese army possessed a completely organized health service.

One should take into account that from the late nineteen century to the early twentieth, the Portuguese army took part in several campaigns to ensure Portugal's sovereignty over its African territories. In general, the forces sent overseas were battalion sized expeditions. It should be noted that, in fact, in all of them, a health section was present. Veritably, the Portuguese army had always assured health support to campaigning troops. Therefore, when war broke out, it was only natural that in all expeditionary forces a health service component was present. However, according to most of the commanding officers of various expeditionary forces, the health personnel were always insufficient in number [12 pp 198-199]. With the II German Reich's declaration of war on Portugal and the deployment of an expeditionary military corps to France, there was an adaptation of the Health Service to the mission's conditions.

As a matter of fact, Portugal, at the beginning of the twentieth century, was a poor and mostly analphabetic nation, since only $30 \%$ of the population could both read, write and do math, although it should be noted such statistic included (as alphabetized), people who could only write their name and were able to resolve a few simple algebraic operations. In 1910, the only university in Portugal, Universidade de Coimbra, had one thousand and two hundred students only [13 pp 209,214]. This meant that the number of medicine graduates in Portugal was extremely scarce. As a consequence, it was difficult to mobilize enough medics and other health personnel for Portuguese military expeditions.

In spite of such situation, it was still necessary to ensure the existence of a sufficient number of medics and paramedics in order to support the military's war effort and the campaigning expeditionary forces. For that reason, the Portuguese government opted to mobilize all available doctors. As such, doctors from 20 to 30 years of age were integrated in the active troops (first echelon) and doctors from 31 to 40 years of age were incorporated in the second echelon, the reserve troops. At the same 
time, it was noted that, if necessary, a third echelon would be mobilized, containing medics aged 41 to 45 , if considered apt for military service. Even so, these troops were not enough, hence, doctors with degrees from closed down institutions or from foreign universities, even if unrecognized by the national certification system, were also mobilized for military duty, through the same process described above. Students starting a course in medicine in public universities ${ }^{1}$ were also mobilized as medics or paramedics, according to the subjects they had taken. A similarly hasty mobilization of personnel happened with paramedics and nurses. Women also started to be accepted as nurses, due to the difficulty in securing a sufficient number of paramedics [4 pp 7-9]. As an author stated, when writing about the mobilization of medics for the Portuguese Expeditionary Corps, Portugal "was bled of medics" [4 p 14].

Upon reaching the fields of France, the Portuguese Expeditionary Corps were integrated in the British Sector and in the British Expeditionary Force (BEF). As such, some medical support to the troops was provided by the British army's Health Service, especially when it came to the evacuation of wounded Portuguese personnel to the Portuguese hospitals in the rear.

Nevertheless, as discussed, the Portuguese expeditionary army's Health Service was also present in the frontlines, and was organized as follows: closest to the front there were first aid posts, at battalion and at brigade level. There was also an Ambulance Service (Serviço de Ambulâncias), which acted much like field hospitals. Two hospitals containing blood storage facilities also existed in Merville and Saint Venant. There were also two specialized hospitals: The Joint Hospital of Medicine and Surgery (Hospital Misto de Medicina e Cirurgia) and the Venereal Disease Hospital (Hospital de Doenças Véneras). Closer to the rear, there operated the Hendaya Portuguese Hospital, which dealt with convalescent troops that could be returned to the front after being healed [2 pp 359-361, 4 pp 16-17].

The Portuguese Expeditionary Corps Health Service's organization resembles that of the Royal Army's Medical Corps organization (RAMC). The RAMC evacuation line started with first aid posts and bearer relay posts at the front line, followed by field ambulance units, where wounded men received primary care, and by the Casualties Clearing Stations, where the lightly wounded were healed, and the seriously wounded awaited evacuation or were retained if deemed unfit for evacuation. The RAMC's structure also included the Base Hospitals and Home Hospitals. $(14,15)$.

The organizational schematics of the British and Portuguese militaries Health Services were, as we have seen, very similar, due to the integration of the Portuguese Expeditionary Corps into the British Expeditionary Force. One of the biggest differences, though, was the Hendaya Portuguese Hospital, created thanks to Portuguese difficulties in evacuating the corps more seriously wounded men to Portugal.

Yet, such was the situation in Europe. Nevertheless, when it came to Africa, a similar health service system was created. Notwithstanding, it is important to men-

1 In 1911, the new Republican regime founded the Porto and the Lisbon Universities. [13 pp 209-210]. 
tion that the first military expeditions to Africa were battalion sized (comprising a contingent of about one thousand men). In fact, only in the 1915 expedition to Angola and the third expedition to Mozambique, in 1916, were expeditions designed to be much bigger, comprising about 5.000 men each. Even so, such military contingents were much smaller than the Portuguese Expeditionary Corps in Flanders, with their 58.000 men.

However, the expeditions to Africa always included a health section and also had a team of medics at their disposal, with which, according to the team's resources and contingent, they could use to support the expeditionary forces, if casualties stayed at levels the medical teams could withstand. It so happened, though, that these expeditions were prone to heavy casualties, mainly due to disease.

Not only that, the Portuguese army's Health Service wasn't as efficient in combat situations as it had seemed to be able to be on paper. By the same token, the Service was more efficient in Europe than in Africa. In fact, in Europe, the Service followed the British military's Health Service organization and was integrated within the British Expeditionary Force structure, as we have already stated. As such, the British military health service gave a helping hand to its Portuguese equivalent. In spite of that though, the Portuguese Health Service proper in Europe was indeed well equipped to support the national expeditionary corps in a reasonable manner.

At the same time, in Europe, most health problems the troops suffered from resulted from the poor physical condition of the majority of military personnel. Such came from the fact that Portugal, a poor, mostly analphabetic nation, where a majority of the population suffered from malnutrition issues, did not have sufficient young men in a physical condition fit enough to be mobilized for a theatre of war as harsh as the one in Europe. Furthermore, many of the fittest young men available came from the richest families in the country and hence, in one way or another, tented to be able to find and see accepted an excuse to avoid the draft. As a matter of fact, because of such drawbacks, a large number of soldiers in the Portuguese Expeditionary Force were not fit for the war campaign. Yet, throughout the Portuguese participation in the war, about 47.000 troops passed by the Portuguese military Health Service in France [4 p 20].

As for the total of men who suffered battles wounds, it was around 5.000 (for reference, 2486 were treated for injuries relating to the exposure to toxic gas, and 2311 were treated for other wounds. As such, a total of 4797 troops saw treatment during the war for battle wounds) [2 pp 361-2].

It should be noted, though, that the total number of wounded personnel was slightly higher, as some wounded men were captured and treated in German POW camps, while others were treated in British hospitals.

The situation in Africa, as we will discuss, was much different. In Mozambique, the Portuguese military health service collapsed in the face of enormous logistical difficulties and deficiencies resulting not only from the German invasion of the territory, but also from the tropical climate of the area, for which the national forces were 
not conveniently prepared. At the same time, the drugs used to treat disease weren't of the best available quality, and the uniforms and boots soldiers wore weren't adequate for such climate.

By the same measure, the fact that many Portuguese troops came from poor rural countryside towns and lacked hygiene habits also made them more prone to diseases like cholera and typhus, as well as others of tropical origin. Venereal diseases were also common among troops sent to Mozambique, and most medics did not have enough knowledge of African health problems and diseases in order to be able to treat them (the study of such exotic ailments was known as "colonial medicine" at the time). [12 pp 200-203].

As a result, the number of deaths by disease in Africa mounted over time. In total, in Mozambique, Portugal suffered a total of 10.000 dead or missing (for reference, the number of soldiers confirmed dead was 4811 , while circa 5500 were considered missing, although probably almost of them were really non confirmed deaths [for numbers, 3 p 522]. As we will observe in the next chapter, this state of things marked the writings of a number of medics who described their experiences as part of one of the military expeditions sent to Mozambique.

\section{Studies, Memoirs and Diaries: From Statistics to Real Life}

Few texts were written on the subject of Portuguese medical presence in World War One. As we have already been able to observe, one of the reasons for such can be that the number of physicians in general, and hence, the number of physicians available to serve as medics, was quite low. By the same measure, many of the ones who did serve, left no record of their experiences.

Yet, that could have its explanation in the fact that, being both professional and cultured, many of these doctors did not see war as a positive experience and consequently, declined to write on the subject. In fact, many followed positivist and progressive ideas, which tended to see war as an abnormality and an aberration that went against the evolution of humanity (in fact, we will be able to observe such positions when discussing Jaime Cortesão’s and Américo Pires de Lima’s work).

As such, the majority of the texts published by Portuguese medics during and after the war were mostly studies in the field of military medicine, and were in general, conference proceedings. Such is the case of two short texts, one from Jorge Monjardino [16], and another form Alberto Madureira [17], both covering the same topic: surgical intervention in war scenarios.

Being that as it may, one of the most curious texts on these subjects came from Portuguese doctor, Reynaldo dos Santos. Santos could be considered an interesting character, mostly because of his role both as an assistant professor at the School of Medicine of the University of Lisbon, as well as one of the most eminent researchers on the field of history of Portuguese art at the time. Nevertheless, however proficient and prolific in his academic pursuits, much like other physicians, he was mobilized 
for war, integrating the Portuguese Expeditionary Corps in France. His stay at the front lasted from 1916 to 1918, as a part of the aforementioned Health Service.

In 1916, Santos published a volume containing two papers he authored, which resulted from a report, which itself was based in a study he had conducted for the Portuguese government, related to World War One campaign treatments. Said report had also been previously presented to the Minister of Education (Ministro da Instrução). In it, Santos spoke of the acceleration of military operations during the Great War and the correlated increase in battle casualties, which, according to him, led to an "eruption of wounded men".

Taking his experiences into account, the Portuguese medic defines three types of war: Chronic war (Guerra Crónica), a type of fighting marked by regular, lowintensity combat; severe war (Guerra Aguda), marked by seldom yet intense clashes; and movement war (Guerra de Movimento) defined by the existence of a large number of physical obstacles that would have to be surmounted in order to achieve victory, notwithstanding possible skirmishes with the enemy. Logically, each type of war also presented its own medical challenges. In fact, in the first type of conflict, regularity and low combat intensity meant a lower number of wounded men, as well as a larger reaction time for health services. By contrast, the two latter types of war were marked, according to Santo's position, by rapidly mounting casualties, or as he himself put it: an "eruption of wounded men" [18].

Reynaldo dos Santos also advises that "good economy includes more than just looking into costs; it also must look for results" [18 p 14]. The Portuguese medic, likewise, and taking such principles into account, puts forward that a well prepared Health Service would be cheaper than a less well prepared one, because its effectiveness in treating wounded soldiers, and consequently avoiding costly and unnecessary losses of troops through death or incapacitation, would outweigh the cost of equipping the Service.

Santos' book also presents the reader with a detailed description of the French Health Service in the Champagne front, resulting from a scientific journey he had undertaken to the area. The work is divided into two chapters, each resulting from one of the papers he presented at different conferences. The first speaks of the organization of the French military's Health Service in the aforementioned front. The second deals with the treatment of wounded men in general, and presents a number of technical details about it. Indeed, what could have been the most interesting side of Reynaldo dos Santos book to the audience that first came into contact with it, was the fact that it presented a description of the real experience the author had gone through. Rather than using an academic tone, Santos described the realities of war and the action of the French Health Service just like he had seen it take place.

By contrast, the paper presented in 1917, during the military exercises in Tancos, and written by Ricardo Jorge, another eminent Portuguese physician, was a much more theoretical work. In the conference he presented it, Jorge spoke about how, in war, disease had the tendency to be much more deadly then wounds suffered 
in battle. In fact, the first time more men had died during battle and of wounds then of disease, was during the Franco-Prussian War, particularly in the Prussian army. Such a situation would only take place again during the Russian-Japanese war. The text concludes by enumerating the diseases that decimated the most armies over time: Cholera, smallpox, typhus, and others [19].

When it came to Júlio Gonçalves [20], a naval medic, he published a small book on the action of the navy's Health Service (Serviço de Saúde Naval em Guerra) in 1917. One of the most interesting ideas present in the work appears when the author discusses the deficiencies that he found to be present in Portuguese colonial military expeditions when it came to medical knowledge of African diseases and pathologies as well as of records of personnel sent overseas. In fact, as we have seen, these deficiencies caused a tragic casualty toll for the Portuguese army in Africa.

Two memoirs produced by Portuguese medics were particularly acclaimed at the time, and continue to be so even today. Likewise, both authors share the commonality of being civilians before mobilization. We speak of Jaime Cortesão and Américo Pires de Lima and their respective memorial writings.

Although both works are organized like a narrative, they are quite different in their elaboration and perspective. One of the reasons for such lies in the spaces where each of the medics operated. In fact, Cortesão served in the Portuguese Expeditionary Corps in Flanders, France, while Pires de Lima was part of the Portuguese Army in Mozambique. Furthermore, Cortesão was an intellectual and a politician who supported Portuguese belligerency. As such, he regards his activity as a medic in the Flanders front line and in the Portuguese war campaign in general through the framework of this ideology.

As for Américo Pires de Lima, by contrast, although also a physician, he was not a political activist. Hence, his narrative shows a critical position on his experience of war. As an element of the Third Portuguese expedition to Mozambique, Lima was deployed in 1916. The third expedition had the mission to penetrate Tanganyika, having to conquer a significant part of the territory, in order to ensure a prime position for Portugal in future diplomatic negotiations over the spoils of war. Nevertheless, the expedition was completely defeated and, as such, the Portuguese government's ambitions ended in disaster.

Lima starts his narrative by condemning war as a "barbaric institution, a monstrous revival of the most vile and stupid animalism"2 [21 p 3].

Following such, at the beginning of his memoirs, he recognizes the painful experience he had to endure as part of the Portuguese expeditionary force in Mozambique, stating also that it had taken some time to develop a more rational and less passionate view of his war experience [21 p 1-2]. Part of his painful memoires, he writes, resulted from the absolute improvidence, not to say incompetence, of the troops sent to war without proper support, including enough medical supplies to

2 "A guerra é uma instituição bárbara, monstruosa revivescência da mais vil e estúpida animalidade" 
pursue a war in Africa. Moreover, against such a strong adversary as were the German Askaris forces; lacking medical support, the Portuguese troops would die en masse not from enemy bullets, but from disease [21 pp 5-6].

Nonetheless, Pires de Lima's memoirs weren't simply about his experience of war in general. Indeed, due to his duties as a medic, many of his reminiscences have to do with his medical work. As such, Pires de Lima presents an extraordinary account of the logistical insufficiencies of the Portuguese military expeditions in Africa, mostly those affecting medical personnel. For example, seeing as though Portugal didn't have enough anti typhus vaccines, the author had to ensure that they were bought in Cape Town in order to vaccinate the expeditionary force he integrated. Due to this work, he writes, few casualties related to disease took place in the third expedition when compared to similar expeditions taking place before, in 1917, which were decimated by illness, due to lack of vaccination [21 pp 15-16].

Pires de Lima also received the mission to inspect the water tank that supplied water to the whole of his expedition. According to his accounts, though, the quality of the water found in said tank was subpar, as it present a milky colour and texture. Thus, the medic recommended setting up a filter using wooden boards. Yet, such a request was denied by the military's engineering corps in charge of these ventures, which stated that such a project would take two months to complete. The Portuguese command of the expedition was also against Pires de Lima's position, arguing that there was no need for such a contraption, since by the time it would have been set up, the campaign would have already ended in victory. The author was, understandably, absolutely furious with the Command's position [21 pp 23-4]. Indeed, he and many of his officer comrades saw their deployment in Mozambique as form of exile and were not happy to have to withstand it [21 p 28]. The author was also astonished at how one of the oldest colonial countries in Europe was incapable of understanding the dangers posed by the African climate and endogenous diseases.

To make the situation worse, the Portuguese campaign hospital took a large amount of time to finish building and the materials used to do it were almost all unsuitable for the territory and climate in question [21 p 28]. Indeed, Pires de Lima's work presents the reader with a myriad of perplexities the author faced, as well as his reactions to the lack of planning and organization of the third Portuguese expedition to Mozambique. The medic also writes about a number of absurdities, as he put it, a concept he mostly connects with the ideas put forward by the expedition's command, which, according to him, was prolific in its use of what he saw as senseless drivel. He writes: "human endurance has limits and war isn't fought with words."3 [21 p 49].

Nonetheless, Américo Pires de Lima shows that he concerned himself with subjects beyond medical issues. In fact, his memoirs include other themes, such as his fascination with Africa and particularly with its animals, of which the Mocímboa da Praia Lions were an example of. A few Philosophical writings about humanity can

3 "Mas a resistência humana tem limites e a guerra não se faz com frases." 
also be found. Indeed, Pires de Lima often finds himself puzzled by questions raised by the war concerning humanity and the Subject [21 pp 33-45,85-88].

As a medic, he also observed how the poor logistical and medical organization of the expeditionary forces affected wounded troops in Africa. In Europe, by contrast, the wounded were assisted quite quickly and all resources needed for treatment tended to be available. In Africa, though, he writes, the wounded, if shot, were lucky to survive. In his own words: "Those that fought in Europe, when wounded, had their care and medical assistance guaranteed for the most part and with full usage of available resources. In Africa, if caught in a surprise attack, the wounded were lucky the bullet hit them in a good spot."' $[21$ p 60].

For Pires de Lima, the fiasco that was the expedition to Mozambique he participated in, created a disrespectful sentiment towards Portuguese power among the indigenous population. To him, black people only respected the exertion of power through force, yet, unfortunately, the Portuguese displayed characteristics of being weak rulers [21 p 64], which went against his position that it was crucial to maintain the native's respect for the white race in Africa, "and the prestige of its superiority" [21 p 82].

A year later, in 1917, Pires de Lima would expose and criticize the existence of the same errors in the organization of the Mocímboa de Praia military base. Regarded as the "Sintra of Niassa", the town was built on swampy and marshy ground, which, because of the terrain's humid characteristics, made the area favorable to the spread of disease. In light of such, many of the Portuguese troops that disembarked in Mocímboa da Praia were decimated without shooting a bullet [21 pp 88-98].

It should also be noted that Pires de Lima's memoirs were impregnated with disillusions and melancholia, but these reflected less of a political or ideological disappointment and more of a saddening individual experience, resulting from his participation in an activity which he believed was archaic and barbaric, on the one hand, and dealt with incompetently by the Portuguese government and military commands, with complete disregard for the life of Portuguese soldiers, on the other. As it happens with Américo Pires de Lima, Jaime Cortesão sees war as capable of causing "infinite misery" [22 p 25]. Yet, in contrast to Américo Pires de Lima, it is also seen as a needed and patriotic endeavor. In that measure, the author metaphorically described the way one should see war as: a star that, if looked upon from close quarters, is a destructive body of fire and lava. Yet, if seen from a distance, it becomes an object of beauty, emanating clarity [22 p 26].

In that sense, Portuguese intervention in World War One was regarded as a necessary evil. A fight that needed to be fought for the sake of Portuguese independence and sovereignty over of its overseas territories, landmasses which brought

\footnotetext{
4 "Os que se batiam na Europa, quando feridos, dentro de pouco tempo, geralmente, tinham garantido o socorro e a assistência médica com todos os seus recursos. Na África, num ataque surpresa, a sorte dos feridos era que a bala lhes acertasse num bom lugar."
} 
forward the ambition of control over them by II German Reich. Hence, military intervention was viewed as a grand duty for the future of the fatherland [22 pp 28-30]. Such a position permeates all of Cortesão's narrative. Therefore, one can appreciate why he refused a position as a medic on a calmer area of deployment of Portuguese medical personnel. In fact, Cortesão wished to serve at the front [22 p 65].

He arrived at the trench lines in November 1917. In his narrative, he contrasts the misery lived in the trenches with the sense of duty, sacrifice and courage which, during war, made men become distinguished for their actions, a distinction that went beyond class and social hierarchy [22 pp 67-68]. Such meritocratic view, it should be noted, is typical of all Portuguese republican ideologues.

Although he saw the hardships the Portuguese Expeditionary Corps went through, Jaime Cortesão remained incapable of criticizing Portugal's interventionist governments. In spite of immense difficulties, intervention in the world war was regarded as such an important fact, that Norton the Matos, the ministry of war as "possessing tremendous will", which helped the country to pursue its noble mission [22 p 33].

In light of such, the suffering of the troops was seen as resulting more from the misery caused by combat and from the action of the enemy, then from Portugal's difficulty in supporting its war effort in general. In fact, during Sidónio Pais' government, deficiencies in the Portuguese war effort were considered to be a result of Sidónio Pais own "germanophilia".

When it comes to Jaime Cortesão, the author writes not only about his own experience of war, but also about the Portuguese presence in the war in general. That presence and the thoughts arising from it appear in short stories that punctuate the book and serve as a mirror for the ideas concerning the argued existence national heroic characteristics and idiosyncrasy. As an example, one may present what the author writes about the attitude of Captain Gonzaga, who was severely wounded in a trench raid, arguing he possessed: "(...) a joyful and youthful smile which appears most profound in those who despises death" [22 p 116]. Many of the stories that Cortesão tells are related to the experience that he had as a medic in the front lines. At certain points in his work, he goes as far as describing the behavior of gassed and of dying men [22 pp 128-131]. However, one of the most terrible experiences the medic described, happen to him. In fact, at one point during the course of the war, he was himself gassed, an incident which left him blind.

In his work, he describes many of the dreadful moments he lived, which led him to a crushing realization: his medical knowledge and training, however ad-

5 Sidónio Pais' government, which resulted from an alliance of almost all the parties that were against the interventionist republicans, wasn't actually germanophile, since, in fact, it was supported by Great Britain. However, interventionist republicans saw Sidónio Pais' policy making as anti-interventionist, which was, in part, correct. Hence, he was quickly considered to be a germanophile. That view was also fueled by the fact that Sidónio Pais was the Portuguese ambassador in Germany before the 1916 declaration of war. 
vanced, could not impede him from becoming paralyzed by the terror the fact that his blindness was to probably become permanent brought. Such is, in our opinion, one of the most interesting moments in the book. In Cortesãos mind raged a war between his rational medical training and analytical experience, which told him that his blindness would come to pass, and the emotional, irrational felling the he would be blind forever. In fact, as one is able to observe by reading the medic's account, in spite of being one of the most relevant Portuguese intellectuals of the time, his irrational feelings about the ailment that plagued him, many times ended up overcoming the more rational side of his thought [22 pp 133-137].

Notwithstanding, as a sufferer of a condition directly related to the war being fought, Cortesão was in a place in which the concept of heroism could more easily arise within his thought. Indeed, within this framework, wounded men could be seen as an incarnation of a number of heroic qualities: endurance and resistance, for example. Jaime Cortesão himself argued for it many times. As a matter of fact, for an interventionist intellectual and political activist, the relationship between wounds and heroism was a likely and clear one. As the author put it, at the end of his book: Portuguese soldiers were men in suffering, in pain and in heroism [22 p 161].

Another interesting memoir was written by Manuel Hermenegildo Lourinho during his later years. The book in question had 2 editions, in 1980 and in 2006 [23]. However, most of his work is about what he went through as a POW. Nevertheless, his position as a medic is still part of his writings, since the author criticizes the German authorities that managed the camp for not letting imprisoned medics exercise their profession [ 23 p 105]. By the same measure, the author criticizes the same authorities for not obeying international law when it came to the way medics should be treated, arguing that though he and other Portuguese officers served in the army, according to international regulations, medics were considered to be non-combatants and should, hence, be set free [23 pp 106-107].

The diary of Raul de Carvalho, a young medic mobilized to serve in the Portuguese Expeditionary Corps, is also a memoir one should take into account, also considering the fact that it was only recently published. This particular diary is quite interesting, given the fact its own author forgot the pages that form it amidst his own papers. Despite such, all parts of the diary were recently discovered and reorganized in order to match their sequence at the time of writing. One could argue, Carvalho's view presents a genuine look at the realities of war, since it was written from a firsthand experience.

As such, the author presents similar positions to other Portuguese medics on shared topics, one of them being the idea that war was first and foremost a tragedy, and a personal one at that, in the case of Carvalho, since, he writes, it took him away from his beloved family and country, and threw him into a terrible nightmare. In his own words: "war, in essence, is death; nothing more" [24 p 80]. Nevertheless, Carvalho also finds a much more positive side to the experience of war. Stating later in his work that, for him and most of his colleagues, war, at times, was: "sleeping, 
eating and having fun" [24 p 44]. Indeed, the Portuguese medic served in rearguard hospitals, where the fighting only arrived in the form of wounded men. As such, he spent most of his free time visiting local towns and dinning with his colleagues and other Portuguese officers. Despite such favorable remarks about the experience of war, the diary does contain several instances where Carvalho speaks of his service as a medic. In fact, in various occasions, we see the author administering injections and vaccines, as well as discussing the Portuguese troops' ration, which he wrote a report on, describing it as insufficient in bread, salt and fat but overabundant in meat products [24 pp 123-124]. Raul de Carvalho also speaks of bitter rivalries between Portuguese and British medics when in British hospitals, yet, he argues, such contentions were caused by the Portuguese officers' ability to form closer relationships with French females, then their British counterparts [24 pp 72,155].

Nevertheless, less encouraging moments were also part of Carvalho's experience. In fact, the Portuguese medic had to endure German Bombardments when in Calais. But in contrast to Jaime Cortesão, the author never served in the front line. By the same measure, when he had the possibility of returning to Portugal under leave, he welcomed it with great joy, never returning to the fields of Flanders until the end of the war, given the evolution of Portuguese politics during the last months of 1917.

One should take into account that neither Raul de Carvalho, nor Pires de Lima supported Portuguese intervention in the war. Like many others, though, both medics were compulsorily mobilized. As such, it is understandable that both present a negative vision of war in general and of the Great War in particular. By the same measure, the Portuguese government's political and military course of action concerning the war strengthened their views on what they considered to be its more barbaric aspects.

\section{Conclusion}

As a closing remark, one can start by acknowledging that there were few texts written on the Portuguese military Health Service's actions during World War One. However, all of the Portuguese branches of the armed forces at the time: the Navy and the Army, had a Health Service in place during peace time. In fact, the army had a Health Service Department connected to it's the General Staff at its disposal, as well as a company connected to the Health Service in each division. There were also several military hospitals spread throughout continental Portugal. However, notwithstanding such an organized scheme of forces, full national mobilization was still an issue, although due to social, more than military, areas of shortage.

As we have established, Portugal had a deficit of trained medics. Due to such fact, the army was forced to mobilize medicine students, without a fully completed academic course in their field of choice, as well as medics without proper knowledge for the war theaters they had to operate in. 
In the fields of France though, the deficiencies the Portuguese army suffered from were able to me made less evident by the presence of the Royal Army Medical Corps and by a more significant mobilization of Portuguese personnel to the military's Health Service. In Africa, though, things went wrong almost since the beginning, mostly because the Portuguese military expeditions were lacking medical personnel and many medics present in the African theatre did not have sufficient knowledge of endogenous diseases. As a consequence of such lack of preparation to deal with the conditions of the pathological environment, casualties in Portuguese expeditions mounted to very large numbers over time.

As for works concerning Portuguese medics' experience of war, they took on several forms. Some specialists focused on the technical knowledge that could be taken from combat medicine, writing about the organization of the military's Health Service, as well as the treatment of wounded men. These technical works, by their own nature, tend to either try or bring forth practical knowledge about medicine in times of war, or to present theoretical theses on past instances of the use of combat medicine.

Another group of works by Portuguese medics tends to focus more on memorial writing, describing personal experiences of war. In such books, the technical knowledge of medicine under conditions of war and the theorization about such topics appear side by side with other experiences related to the conflict. In fact, the authors not only describe medical procedures, but also speak of their feelings on the war itself.

Lastly, it is possible to conclude that, in fact, few books were written on these subject matters during the war and after it. Even today in Portugal, such trend continues, as these topics remain largely marginal when it comes to scientific research into history and medicine.

\section{Rezime}

Iako su početkom 20. veka svi vidovi portugalskih oružanih snaga imali svoju zdravstvenu službu, Prvi svetski rat je jasno pokazao nedostatke tog sistema. Razlozi za to su bili prevashodno društvene prirode - postojao je znatan nedostatak lekara i obučenih medicinskih tehničara. Stoga je vojska bila prinuđena da regrutuje studente medicine, koji često nisu u potpunosti završili svoje izabrane kurseve, kao i tehničare koji nisu imali odgovarajuća znanja koja bi im omogućila rad na bojištima na koja su bili poslati.

Ti problemi nisu bili toliko uočljivi na frontu u Francuskoj, zbog prioriteta u dodeli ljudstva koji je to ratno poprište imalo, kao i zbog prisustva savezničkih medicinskih službi. Međutim, u Africi je taj problem bio naročito izražen, jer tamo nije moglo da bude upućeno dovoljno medicinskog osoblja; oni koji bi tamo ipak bili poslati nisu posedovali dovoljno znanja o tretmanu bolesti karakterističnih za to podneblje. Stoga su neborbeni gubici u Africi bili veoma visoki. 
Što se tiče dela u kojima su opisana ratna iskustva portugalskih lekara, ona se mogu podeliti na ona posvećena reorganizaciji zdravstvene službe na osnovu ratnih iskustava, i ona prevashodno memoarskog karaktera. Prvu grupu pre svega čine tehnički radovi koji za cilj imaju da prenesu praktična znanja o ratnoj medicini ili koji nastoje da daju teorijski prikaz prethodne upotrebe ratne medicine. Druga grupa nije toliko usmerena na tehničke aspekte medicinskih procedura, već se u njima izlaže pogled autora na lični doživljaj rata. $\mathrm{O}$ ovoj temi nije puno pisano u godinama nakon Prvog svetskog rata, a čak i danas se ona nalazi na margini naučnog interesovanja za istoriju medicine.

\section{References}

1. Almeida C. Intervenção do Ministro da Marinha, Celestino de Almeida [Intervention by the Minister of the Navy, Celestino de Almeida]. Diário da Câmara dos Deputados. 1911. Sessão No 11 de 15 de Dezembro, p. 4.

2. Fraga LA. Saúde e Apoio Sanitário. Salvar Vidas! [Health and Sanitary Support. Save lives!] In: Afonso A, Gomes CM, editors. Portugal na Grande Guerra, 1914-1918. Matosinhos: Quidnovi; 2010. 359-62.

3. Fraga LA. Portugal e a Grande Guerra. Balanço e Estatísticas [Portugal and the Great War. Balance and Statistics]. In: Afonso A, Gomes CM, editors. Portugal na Grande Guerra, 1914-1918. Matosinhos: Quidnovi; 2010. 520-25.

4. Fraga LA. O Serviço de Saúde no Corpo Expedicionário Português em França [The Health Service in the Portuguese Expeditionary Corps in France]. 1916 - 1918. Available from: http://repositorio.ual.pt/bitstream/11144/523/1/O\%20Servi\%C3\%A7o\%20de\%20 Sa\%C3\%BAde\%20no\%20Corpo\%20Expedicion\%C3\%A1rio\%20Portugu\%C3\%AAs\%20 em\%20Fran\%C3\%A7a_2.pdf. [accessed in 12 October 2017].

5. Portela M. Cuidar das feridas em todas as frentes [Caring for wounds on all fronts]. Visão - História. 2014;25:34-7.

6. Portela M. Jorge Monjardino: experiências de modernidade médica durante a Primeira Guerra Mundial [Jorge Monjardino: experiences of medical modernity during the First World War]. In: Pereira GM, Alves JF, Alves LA, Meireles MC, editors. A Grande Guerra (1914 - 1918): Problemáticas e Representações. [Actas]. Porto: CITCEM; 2015. 67 - 82.

7. Portela M. Estudo Introdutório e Cronologia [Introductory Study and Chronology]. In: Cortesão J. Memórias da Grande Guerra. DHCM/Quartzo Editora; 2016.

8. Meneses FRD. A Grande Guerra de Afonso Costa [The Great War of Afonso Costa]. Alfragide: Dom Quixote; 2015.

9. Afonso A. A Grande Guerra, Angola, Moçambique, Flandres, 1914-1918 [The Great War, Angola, Mozambique, Flanders, 1914-1918]. Lisboa: Quidnovi; 2008.

10. Telo AJ, Sousa PMD. O CEP. Os Militares Sacrificados à Má Política [Military Officials Sacrificed to Bad Politics]. Porto: Fronteira do Caos; 2016.

11. Duarte AP. A Guerra Civil Larvar e a Beligerância Portuguesa na Grande Guerra. A Grande Guerra: um Século Depois (Colóquio na Academia Militar) [The Larvar Civil War and the Portuguese Beligerence in the Great War. The Great War: A Century After]. Lisboa: Fronteira do Caos; 2016. 77- 97. 
12. Arrifes MF. A Primeira Guerra Mundial na África Portuguesa. Angola e Moçambique (1914-1918) [World War I in Portuguese Africa. Angola and Mozambique]. Lisboa: Edições Cosmos/Instituto da Defesa Nacional; 2004.

13. Telo A. Primeira República I, do Sonho à Realidade [First Republic, from Dream to Reality]. Barcarena: Editorial Presença; 2010.

14. Baker C. The evacuation chain for wounded and sick soldiers. Available from: Weblog the Long, Long Trail. The British Army in the Great War. 1914-1918 http://www.longlongtrail.co.uk/soldiers/a-soldiers-life-1914-1918/the-evacuation-chain-for-wounded-andsick-soldiers/ [accessed 10 October 2017].

15. RAMC in Great War (UK). The Chain of Evacuation of the Royal Army Medical Corps. Available from: Weblog http://www.ramc-ww1.com/chain_of_evacuation.php?osCsid=f3 389470af97f7af5a0144589c7f8145 [Accessed in 10 October 2017].

16. Monjardino J. Cirurgia de Guerra [War Surgery]. Conferência Realizada na Faculdade de Medicina de Lisboa em 14 de janeiro. Lisboa: Typographia Adolpho Mendonça; 1918.

17. Madureira A. Cirurgia de Guerra [War Surgery]. Lesões traumaticas do craneo e encéfalo. Lisboa: Typographia de Adolphe Mendonça; 1916

18. Santos RD. A Cirurgia na frente occidental (Maio-Julho de 1916) [Surgery on the Western Front (May-July 1916)]. Separata da Medicina Contemporânea. Lisboa: Typographia Mendonça; 1916.

19. Jorge R. Sanidade em Campanha: conferências proferidas no acampamento de Tancos e na faculdade de medicina de Lisboa em julho e agosto de 1916: $1^{\text {a }}$ conferência [Health in Campaign: lectures given at the Tancos camp and at the medical school of Lisbon in July and August 1916: 1st conference]. Separata dos Archivos do Instituto Central de Higiene. II. Coimbra: Imprensa da Universidade de Coimbra; 1917.

20. Gonçalves J. Serviço de Saúde Naval em Guerra. Postos de Socôrro - Transporte de Feridos - Ambulâncias Expedicionárias [Naval Health Service at War. Socôrro Locations - Transportation of Wounded - Expeditionary Ambulances]. Lisboa: Sociedade Typographica Editora; 1917.

21. Lima, APD. Na Costa d'África (Memórias de um Expedicionário a Moçambique) [On the Coast of Africa (Memoirs of an Expedition to Mozambique)]. Gaia: Edições Pátria; 1933.

22. Cortesão J. Memórias da Grande Guerra, 1916-1919 [Memories of the Great War, 19161919]. Lisboa: Quartzo Editora/Direção de História e Cultura Militar; 2016.

23. Lourinho MH. Prisioneiros Portugueses na Alemanha. 1 a Guerra Mundial. 1917-1918 [Portuguese prisoners in Germany. First World War. 1917-1918]. Prefácio: Lisboa; 2006.

24. Carvalho R. Quando o Raul foi à Guerra. Memórias de um médico português na I Guerra Mundial [When Raul went to war. Memories of a Portuguese doctor in World War I]. Lisboa: Matéria-prima; 2013.

Submitted: 02. 11. 2017.

Reviewed: 13. 11. 2017.

Accepted: 17. 11. 2017. 